\title{
ANALISIS TINGKAT KESEJAHTERAAN, SIKAP, PERILAKU, DAN TINGKAT KEPUASAN KELUARGA SASARAN PROGRAM KONVERSI MINYAK TANAH KE LPG DI KOTA BEKASI
}

\author{
Analysis of Welfare Level, Attitude, Behavior, and Satisfaction Level of Target Family of \\ Kerosene to LPG substitution Program \\ ISTIQLALIYAH MUFLIKHATII ${ }^{1^{*}}$, NOVIDA NURMAYANTI ${ }^{2}$, ALFIASARI $^{1}$ \\ ${ }^{1}$ Staf Pengajar Departemen IImu Keluarga dan Konsumen, Fakultas Ekologi Manusia, \\ Institut Pertanian Bogor, Jalan Lingkar Kampus IPB Dramaga, \\ Bogor 16680 \\ ${ }^{2}$ Departemen Ilmu Keluarga dan Konsumen, Fakultas Ekologi Manusia, Institut Pertanian \\ Bogor, Kampus Dramaga, Bogor 16680
}

\begin{abstract}
Substitution program of kerosene to LPG is one of the government programs, which is very important for energy policy in this country. The aims of this research were to analyze the socioeconomic characteristics of target family and to construct the strategies in order to increase the quality of program. The study was conducted using cross sectional design. It involved 60 families from two villages at Bekasi City as respondents. The result of the study showed that expenditure allocation for fuel in the family respondents decreased after the program. The family welfare was affected by decreasing of expenditures allocation for fuel, wives's occupational status, wives' educational level, and family's attitude in this program. Meanwhile, wives's occupational status and educational level also affected family's attitude in the program. Moreover, family's attitude in the program gave significant effect on the behavior of using LPG. Family's Satisfaction level based on CSI showed that respondents were satisfied with this program.
\end{abstract}

Key words: attitude, behavior, LPG program, satisfaction, welfare

\section{PENDAHULUAN}

Energi sebagai komoditas strategis suatu negara menjadi sangat potensial untuk dikelola demi kesejahteraan masyarakatnya. Indonesia sebagai negara berkembang dihadapkan pada pengelolaan energi yang tepat guna dalam memenuhi kebutuhan masyarakat. Kebutuhan masyarakat akan kebutuhan energi yang tak terhingga harus diiringi tata aturan dan kebijakan yang efektif agar pengelolaan energi dapat berjalan secara berkelanjutan, mengingat jumlah energi pada beberapa jenis sangat terbatas dan tidak dapat diperbaharui. Dalam Anggaran Pendapatan dan Belanja Negara (APBN), pemerintah telah mengalokasikan subsidi energi, khususnya minyak tanah, solar, dan premium. Dalam perkembangan APBN, realisasi subsidi Bahan Bakar Minyak (BBM) sejak tahun 2002 hingga 2005 terus menunjukkan peningkatan yang berarti yaitu dari sekitar $\mathrm{Rp} 30$ triliun menjadi lebih dari Rp 90 triliun. Namun, pada APBN 2006, subsidi BBM mengalami penurunan anggaran menjadi Rp 64,212 triliun dengan alokasi subsidi terbesar adalah untuk subsidi minyak tanah yang mencapai Rp 31,58 triliun (Anonim 2007).

Besarnya subsidi negara terhadap bahan bakar minyak (BBM) dan ketimpangan neraca gas (LPG) dan minyak tanah membuat pemerintah pada tahun 2007 mengeluarkan "Program Konversi Minyak Tanah ke LPG". Pengguna minyak tanah banyak didominasi oleh rumah tangga miskin, sehingga program ini seakan ditujukan untuk rumah tangga miskin. Berbagai masalah sering muncul dalam pelaksanaan program ini, mulai dari harga gas yang lebih mahal dibandingkan minyak tanah (minimal pembelian gas adalah $3 \mathrm{~kg}$, 
sedangkan minyak tanah bisa dibeli untuk $1 / 4$ atau $1 / 2$ atau 1 liter); ketidakmampuan pemerintah menjamin ketersediaan pasokan gas (Kompas 2008); aksesibilitas masyarakat miskin yang rendah terhadap harga LPG 3 $\mathrm{kg}$, sosialisasi yang kurang tentang pemakaian tabung gas, kompor gas, dan aksesoris lainnya; kelemahan data penunjang di lapangan, hingga sulitnya mengubah kebiasaan masyarakat untuk beralih dari minyak tanah ke LPG.

Dari sisi keluarga, program ini berhadapan dengan proses perubahan perilaku dan budaya masyarakat yang sudah biasa menggunakan minyak tanah sebagai bahan bakar dalam memasak menjadi menggunakan LPG. Perubahan ini akan sangat mempengaruhi sikap, perilaku penggunaan dan pola alokasi pengeluaran keluarga. Bagi keluarga miskin, program ini akan sangat berdampak terhadap kondisi kesejahteraannya. Analisis tingkat kepuasan perlu dilakukan mengingat program ini masih belum optimal pelaksanaannya. Hal ini penting untuk dilakukan mengingat pelaksanaan program masih menuai keluhan dari sisi masyarakat sebagai pengguna jasa pemerintah.

Oleh karenanya penelitian ini dilakukan untuk tujuan: (1) menganalisis karakteristik sosial ekonomi keluarga contoh; (2) menganalisis tingkat kesejahteraan keluarga contoh; (3) menganalisis sikap keluarga contoh terhadap Program Konversi Minyak Tanah ke LPG; (4) menganalisis perilaku penggunaan LPG oleh keluarga contoh; (5) menganalisis tingkat kepuasan keluarga contoh terhadap Program Konversi Minyak Tanah ke LPG; dan (6) merumuskan strategi perbaikan pelaksanaan program konversi minyak tanah ke LPG.

\section{METODE}

\section{Desain, Lokasi, dan Waktu}

Desain yang digunakan dalam penelitian ini adalah cross sectional study. Penelitian ini dilakukan di Kecamatan Bekasi Timur, Kota Bekasi. Kecamatan Bekasi Timur dipilih secara purposive karena merupakan kecamatan yang memiliki kepadatan penduduk tertinggi dan memiliki persentase keluarga Pra-KS tertinggi di Kota Bekasi. Kelurahan Duren Jaya dan Margahayu dipilih sebagai kelurahan sasaran secara purposive, dikarenakan dua kelurahan tersebut memiliki rumah tangga miskin paling banyak namun memiliki keunikan lokasi masing-masing. Pengambilan data dilakukan selama 2 bulan yaitu pada bulan Mei-Juni 2009.

\section{Jenis dan Teknik Pengambilan Data}

Data yang digunakan dalam penelitian ini adalah data primer dan data sekunder. Penelitian dilakukan secara survei dengan menggunakan kuesioner. Data primer yang dikumpulkan dalam penelitian ini meliputi data mengenai: karakteristik sosial ekonomi keluarga contoh (umur suami, umur istri, besar keluarga, pekerjaan suami, pekerjaan istri, tingkat pendidikan suami, tingkat pendidikan istri, pendapatan keluarga); alokasi pengeluaran, sikap, perilaku, tingkat kepuasan dan kepentingan contoh, dan tingkat kesejahteraan keluarga contoh.

\section{Contoh dan Metode Penarikan Contoh}

Populasi penelitian ini adalah seluruh keluarga di Kota Bekasi yang menerima program konversi minyak tanah ke LPG. Contoh adalah keluarga yang merupakan sasaran program konversi minyak tanah ke LPG. Pengambilan contoh dilakukan secara acak proporsional pada masing-masing RT terpilih di setiap lokasi kelurahan terpilih. Dari dua kelurahan terpilih (Margahayu dan Duren Jaya), dipilih masing-masing satu RW yang memiliki keluarga miskin terbanyak. Selanjutnya, pada RW terpilih, dipilih secara purposive RT yang memiliki keluarga miskin terbanyak. Oleh karenanya, di Kelurahan Margahayu dipilih dua RT di wilayah RW 09 dan di Kelurahan Duren Jaya dipilih tiga RT di wilayah RW 06. Di masing-masing RT dipilih contoh secara acak proporsional, sehingga penelitian ini melibatkan 60 contoh rumah tangga penerima Program Konversi Minyak Tanah ke LPG.

\section{Pengolahan dan Analisis Data}

Data yang diperoleh terlebih dahulu diedit, ditabulasikan, dan diberi kode. Data yang telah dikumpulkan dianalisis secara statistik inferensia dan deskriptif. Pengolahan data dilakukan dengan bantuan komputer menggunakan program Microsoft Excel dan SPSS for Windows. Data karakteristik keluarga, sikap, perilaku, serta alokasi pengeluaran keluarga contoh dianalisis secara deskriptif. Analisis statisik inferensia yang digunakan pada penelitian ini adalah uji korelasi Pearson dan Spearman, uji beda Mann-Whitney dan paired t-Test, serta regresi linear berganda dan logistik. 
Analisis data yang digunakan untuk menjawab masing-masing tujuan adalah sebagai berikut:

1. Karakteristik sosial ekonomi keluarga contoh dianalisis menggunakan statistika deskriptif untuk memberi makna terhadap data. Untuk menganalisis kondisi ekonomi dilakukan dua pendekatan yaitu pendapatan per kapita dan pengeluaran per kapita. Untuk melihat perbedaan karakteristik sosial ekonomi antara dua perilaku penggunaan LPG digunakan statistik inferensia uji beda Mann-Whitney dan independent $t$-Test.

2. Tingkat kesejahteraan diukur menggunakan pendekatan pendapatan per kapita yang dibandingkan dengan garis kemiskinan Kota Bekasi yaitu sebesar Rp 233.535,00 (BPS Kota Bekasi 2007). Untuk menganalisis faktor-faktor yang mempengaruhi kesejahteraan digunakan analisis regresi logistik dengan rumus :

$P(y)=\frac{e^{\alpha+\beta 1 \times 1+\beta 2 \times 2+\beta 3 \times 3+\beta 4 \times 4+\beta 5 \times 5+\beta 6 \times 6+\beta 7 D 1}}{1+e^{\alpha+\beta 1 \times 1+\beta 2 \times 2+\beta 3 \times 3+\beta 4 \times 4+\beta 5 \times 5+\beta 6 \times 6+\beta 7 D 1}}$

$$
\begin{array}{ll}
\mathrm{X}_{1} & : \text { Jumlah anggota keluarga } \\
\mathrm{X}_{2} & : \text { Umur suami } \\
\mathrm{X}_{3} & : \text { Umur Istri } \\
\mathrm{X}_{4} & : \text { Pendidikan istri } \\
\mathrm{X}_{5} & : \text { Sikap terhadap program } \\
\mathrm{X}_{6} & : \text { Penurunan persentase bahan bakar } \\
\mathrm{D}_{1} & : \text { Pekerjaan istri } \\
\mathrm{P}(\mathrm{y}) & : \text { Peluang tingkat kesejahteraan }
\end{array}
$$

3. Sikap diukur dengan menggunakan sepuluh pernyataan yang masingmasing mewakili komponen sikap, kognitif, afektif, dan konatif. Skala yang digunakan adalah skala Likert yang terdiri dari empat peringkat, jawaban sangat setuju diberi bobot 4 , jawaban setuju diberi bobot 3 , jawaban tidak setuju diberi bobot 2, dan jawaban sangat tidak setuju diberi bobot 1. Untuk melihat sikap contoh, penelitian ini mengoperasionalkannya menjadi dua kategori yang interval kelasnya dibuat dengan rumus sebagai berikut (Slamet 1993) :

$$
\mathrm{I}=\frac{\mathrm{NT}-\mathrm{NR} \mathrm{s}}{\text { Jumlah Kelas }}
$$

I = Interval Kelas

NT = Nilai Tertinggi

$\mathrm{NR}=$ Nilai Terendah
Selanjutnya akan didapat hasil selang sikap yaitu sikap positif (26-40) dan sikap negatif (10-25). Untuk menganalisis faktor-faktor yang mempengaruhi sikap keluarga contoh terhadap program, digunakan analisis regresi linear berganda dengan rumus :

$$
\begin{aligned}
& y=\alpha+\beta 1 \times 1+\beta 2 \times 2+\beta 3 \times 3+\beta 4 D 1+\beta 5 D 2 \\
& \mathrm{X}_{1} \text { : Umur suami } \\
& \mathrm{X}_{2} \text { : Pendidikan suami } \\
& \mathrm{X}_{3} \text { : Pendidikan istri } \\
& \mathrm{D}_{1} \text { : Pekerjaan suami } \\
& \text { ( } 1=\text { bekerja, } 0=\text { tidak bekerja) } \\
& D_{2} \text { : Pekerjaan istri } \\
& \text { ( } 1=\text { bekerja, } 0=\text { tidak bekerja) } \\
& \text { y : Sikap terhadap program }
\end{aligned}
$$

4. Perilaku keluarga contoh terhadap program konversi minyak tanah ke LPG dianalisis secara deskriptif dan dilakukan pengkategorian.

Perilaku yang dimaksud dalam penelitian ini adalah perilaku penggunaan LPG yaitu perilaku terkait dengan bagaimana contoh menerima program dan menggunakan produk program yang dikategorikan menjadi perilaku A (menerima program konversi dan menggunakan produk program) dan perilaku B (menerima program konversi, namun contoh tidak menggunakan produk program). Analisis dilakukan secara deskriptif untuk mengetahui jumlah contoh yang memiliki kategori perilaku tersebut. Hal yang sama juga dilakukan terhadap analisis alasan terjadinya perilaku tersebut. Selain perilaku penggunaan LPG, perilaku penggunaan lain yang dianalisis yaitu perilaku mengkonsumsi atau menggunakan produk program, yang mencakup beberapa atribut seperti tempat pembelian, cara pembelian, dan cara bertransaksi. Untuk mengetahui faktor-faktor yang mempengaruhi perilaku penggunaan LPG digunakan analisis regresi logistik dengan rumus:

$$
\begin{aligned}
& P(y)=\frac{e^{\alpha+\beta 1 \times 1+\beta 2 \times 2+\beta 3 \times 3+\beta 4 \times 4+\beta 5 D 1+\beta 6 D 2}}{1+e^{\alpha+\beta 1 \times 1+\beta 2 \times 2+\beta 3 \times 3+\beta 4 \times 4+\beta 5 D 1+\beta 6 D 2}} \\
& X_{1}: \text { Besar keluarga } \\
& X_{2}: \text { Umur suami } \\
& X_{3}: \text { Umur istri } \\
& X_{4}: \text { Sikap terhadap program } \\
& D_{1}: \text { Pekerjaan suami } \\
& D_{2} \quad \text { : Pekekerjaan istri } \\
& P(y) \text { : Peluang perilaku pengerja) } \\
& P(1=\text { bekerja, } 0=\text { tidak bekerja) }
\end{aligned}
$$


5. Tingkat kepuasan keluarga contoh terhadap Program Konversi Minyak Tanah ke LPG dianalisis menggunakan dua metode, yaitu Customer Satisfaction Index (CSI) dan Importance Performance Analysis (IPA).

6. Strategi untuk memperbaiki pelaksanaan program konversi minyak tanah ke LPG diperoleh dari sikap keluarga dan beberapa dimensi penting dari perhitungan CSI dan IPA serta dilakukan pengembangan sesuai pelaksanaan program.

\section{HASIL DAN PEMBAHASAN}

\section{Karakteristik Sosial Ekonomi Keluarga Contoh}

Karakteristik besar keluarga menunjukkan bahwa separuh keluarga contoh $(50 \%)$ yang menggunakan LPG merupakan keluarga dengan kategori kecil ( $\leq 4$ orang) sedangkan kondisi berbeda terjadi pada keluarga contoh yang tidak menggunakan LPG. Separuh dari keluarga contoh yang tidak menggunakan LPG adalah keluarga yang termasuk kategori besar ( $\geq 7$ orang). Namun hasil uji beda menunjukkan tidak ada perbedaan yang nyata $(p>0,05)$ antara besar keluarga pada keluarga yang menggunakan LPG dengan yang tidak menggunakan LPG.

Rata-rata usia suami contoh adalah 45,94 tahun. Lebih dari separuh suami contoh $(58,33 \%)$ masuk kategori usia dewasa menengah. Kondisi berbeda terjadi pada rata-rata usia istri, yang memperlihatkan bahwa rata-rata usia istri lebih muda dibandingkan usia suami yaitu 42,40 tahun. Persentase istri yang berada pada kategori usia dewasa menengah pun lebih besar yaitu sebesar $65,52 \%$.

Pada kasus Konversi Minyak Tanah ke LPG, idealnya tingkat pendidikan yang tinggi akan membuat keluarga contoh lebih mudah menyerap inovasi program dan menggunakan produk program. Data menunjukkan suami yang memiliki tingkat pendidikan Tamat SLTP lebih besar peluang persentasenya untuk menggunakan LPG dengan persentase sebesar 31,43\%, dibandingkan suami dengan tingkat pendidikan lebih rendah yaitu tamat SD yang lebih berpeluang tidak menggunakan LPG dengan persentase sebesar $53,85 \%$. Namun hasil uji beda yang dilakukan tidak menunjukkan ada perbedaan yang nyata $(p>0,05)$ dalam hal tingkat pendidikan suami antara keluarga yang menggunakan LPG dengan yang tidak.
Kondisi yang berbeda terjadi pada tingkat pendidikan istri. Hasil penelitian memperlihatkan kecenderungan bahwa semakin rendah tingkat pendidikan istri maka akan diikuti perilaku tidak menggunakan LPG. Kondisi ini dapat dilihat dari perilaku tidak menggunakan LPG. Lebih dari separuh keluarga contoh $(53,85 \%)$, adalah keluarga dengan istri yang mempunyai tingkat pendidikan tidak sekolah. Hal ini didukung dengan hasil uji beda yang menunjukkan bahwa terdapat perbedaan yang nyata $(p<0,05)$ pada tingkat pendidikan istri antara keluarga yang menggunakan LPG dengan yang tidak.

Hasil penelitian ini juga menunjukkan tidak adanya perbedaan status pekerjaan suami pada keluarga yang menggunakan LPG dengan yang tidak. Hal ini dikarenakan hanya sebesar $5,71 \%$ suami yang tidak bekerja, sehingga persentase suami yang bekerja memiliki persentase yang hampir merata di dua perilaku. Hasil uji beda juga menunjukkan tidak ada perbedaan $(p>0,05)$ status pekerjaan suami antara dua perilaku penggunaan LPG oleh keluarga contoh.

Kondisi yang lebih beragam terjadi pada status pekerjaan istri. Istri yang bekerja memiliki persentase lebih besar pada keluarga yang tidak menggunakan LPG yaitu sebesar $69,23 \%$. Sebaliknya, pada keluarga yang menggunakan LPG, lebih dari separuh keluarga contoh $(55,56 \%)$ merupakan istri yang tidak bekerja. Kondisi yang berbeda ini dapat dimungkinkan karena status pekerjaan akan mempengaruhi akses informasi yang berbeda kepada setiap orang. Informasi negatif yang terlalu banyak kepada istri akan membuat istri lebih sulit untuk menerima program terutama untuk menggunakan produk program. Namun hasil uji beda menunjukkan tidak ada perbedaan jenis pekerjaan istri antara dua perilaku penggunaan LPG $(p>0,05)$.

Karakteristik ekonomi keluarga contoh memperlihatkan bahwa tidak ada perbedaan pendapatan per kapita antara keluarga contoh yang menggunakan LPG dan yang tidak menggunakan LPG. Hasil uji beda yang dilakukan juga mendukung hal tersebut $(p>0,05)$.

Persentase pendapatan per kapita per bulan terbesar dari keluarga contoh $(51,67 \%)$ berkisar antara Rp 300.000,00 - 499.000,00. Hal ini menggambarkan bahwa lebih dari separuh contoh telah bisa memenuhi pendapatan Rp 10.000,00/orang/harinya. Kondisi ini tentu saja menunjukkan pen- 
dapatan per kapita keluarga yang masih rendah bila menggunakan standar World Bank \$2 per hari. Hal ini juga ditunjukkan dari $25 \%$ keluarga contoh yang masih memiliki pendapatan per kapita per bulan dalam kisaran $\operatorname{Rp} 150.000,00$ - 299.000,00.

Sementara itu, pengeluaran per kapita per bulan contoh dikelompokkan menjadi dua kategori berdasarkan rata-rata pengeluaran per kapita Kota Bekasi yaitu sebesar Rp 589.907,00 (BPS Jabar 2007). Hampir seluruh keluarga contoh $(90 \%)$ berada dibawah rata-rata pengeluaran per kapita Kota Bekasi. Persentase terbesar berada pada pengeluaran per kapita Rp 104.167,00 sampai $\operatorname{Rp} 589.906,00$ baik pada keluarga contoh yang menggunakan LPG maupun yang tidak menggunakan LPG.

Hasil penelitian ini juga menunjukkan adanya perubahan persentase pengeluaran keluarga contoh sebelum dan sesudah program dilakukan. Perubahan itu memperlihatkan bahwa ada beberapa alokasi pengeluaran yang mengalami kenaikan dan ada juga yang mengalami penurunan. Secara keseluruhan, alokasi pengeluaran keluarga yang mengalami kenaikan setelah program konversi dilakukan adalah pengeluaran pangan, pengeluaran kesehatan, pengeluaran untuk rokok dan pengeluaran lain-lain. Hasil uji beda menunjukkan bahwa pengeluaran untuk pangan berbeda nyata $(p>0,05)$ antara sebelum dan sesudah program.

Secara keseluruhan, alokasi pengeluaran keluarga contoh yang mengalami penurunan setelah program dilakukan adalah pengeluaran untuk pendidikan, pengeluaran untuk pakaian, dan pengeluaran untuk bahan bakar. Hasil uji beda menunjukkan bahwa pengeluaran untuk pendidikan, pakaian, dan bahan bakar berbeda nyata $(p<0,05)$ antara sebelum dan sesudah program. Hasil ini mengindikasikan bahwa sebenarnya program konversi membantu meringankan alokasi pengeluaran keluarga untuk bahan bakar. Hanya saja yang perlu dicermati adalah bahwa penghitungan alokasi pengeluaran ini adalah dalam satu bulan. Hal ini tentu saja menjadi kurang berarti bagi keluarga sasaran yang pola pendapatannya adalah harian dan tidak menentu.

\section{Tingkat Kesejahteraan}

Untuk menganalisis tingkat kesejahteraan keluarga contoh, data pendapatan per kapita per bulan keluarga dibandingkan dengan garis kemiskinan Kota Bekasi yaitu sebesar Rp 233.535,00 (BPS Kota Bekasi 2007). Data menunjukkan bahwa terdapat lebih dari separuh keluarga contoh $(60 \%)$ masuk kategori miskin, dan sisanya sebesar $40 \%$ masuk kategori sudah sejahtera. Kondisi ini memperlihatkan bahwa lebih dari separuh keluarga contoh belum bisa memenuhi kebutuhan dasar keluarganya baik pangan maupun nonpangan.

Jika dibedakan berdasarkan perilaku penggunaan, pada keluarga yang tidak menggunakan LPG, lebih dari dua pertiga $(78,57 \%)$ keluarga contoh tergolong kategori miskin. Namun tidak ada perbedaan yang nyata $(p>0,05)$ pada tingkat kesejahteraan antara keluarga yang menggunakan dan tidak menggunakan LPG.

Kesejahteraan suatu keluarga sangat dipengaruhi oleh berbagai faktor. Berdasarkan hasil analisis, faktor yang paling berpengaruh terhadap kesejahteraan keluarga adalah pendidikan istri, pekerjaan istri, sikap terhadap program dan penurunan persentase alokasi pengeluaran bahan bakar. Dari model regresi logistik yang disusun untuk menganalisis faktor-faktor yang berpengaruh terhadap tingkat kesejahteraan diperoleh hasil bahwa variabel-variabel dalam model tersebut dapat menjelaskan $76,1 \%$ faktor-faktor yang berpengaruh terhadap tingkat kesejahteraan keluarga contoh $\left(R^{2}=0,761 ; p=0,08\right)$. Apabila dirinci untuk masing-masing variabel yang berpengaruh nyata, diperoleh hasil bahwa sikap keluarga contoh terhadap program berpengaruh nyata terhadap tingkat kesejahteraan keluarga. Keluarga yang memiliki sikap positif terhadap program berpeluang 4,725 kali lebih sejahtera dibandingkan keluarga yang memiliki sikap negatif. Begitu juga dengan penurunan persentase alokasi pengeluaran keluarga untuk bahan bakar. Selama program konversi, ternyata penurunan persentase alokasi pengeluaran keluarga utnuk bahan bakar memberikan peluang 72,893 kali bagi keluarga contoh untuk lebih sejahtera. Hal ini tentu saja menunjukkan adanya pengaruh nyata program konversi terhadap tingkat kesejahteraan keluarga. Hanya saja yang menarik dari hasil penelitian ini adalah bahwa status istri bekerja ternyata menurunkan peluang keluarga untuk sejahtera sebesar 0,1 . Meskipun peluangnya sangat kecil, namun perlu dicermati bahwa meskipun istri bekerja, peluang kesejahteraan keluarga bisa menurun akibat jumlah anggota keluarga yang besar. 


\section{Sikap terhadap Program}

Hasil penelitian menunjukkan secara keseluruhan lebih dari setengah (55\%) keluarga contoh memiliki sikap negatif terhadap program dan sisanya $(45 \%)$ memiliki sikap positif. Pada keluarga yang tidak menggunakan LPG, hampir seluruh $(92,86 \%)$ keluarga contoh memiliki sikap negatif terhadap program dan lebih dari separuh $(56,52 \%)$ keluarga contoh yang menggunakan LPG memiliki sikap positif terhadap program. Hasil uji beda menunjukkan perbedaan nyata $(p<0,05)$ pada sikap antara keluarga contoh yang menggunakan LPG dengan yang tidak menggunakan. Keluarga contoh yang menggunakan LPG lebih bersikap positif terhadap program daripada keluarga yang tidak menggunakan LPG.

Sikap adalah komponen yang tidak bersifat statis, namun dinamis dan sangat dipengaruhi oleh berbagai faktor. Dalam penelitian ini, berdasarkan hasil analisis faktor, yang paling berpengaruh terhadap pembentukan sikap contoh terhadap program adalah tingkat pendidikan dan pekerjaan istri $(p=0,000$ dan $p=0,020)$.

Model regresi berganda yang disusun dalam penelitian ini menunjukkan bahwa $36 \%$ faktor yang berpengaruh terhadap sikap keluarga contoh dapat dijelaskan dari variabel-variabel dalam model tersebut $\left(R^{2}=0,36\right)$. Berdasarkan rincian variabel yang secara nyata berpengaruh terhadap semakin positifnya sikap keluarga contoh terhadap program $(p=0,000)$. Sementara itu, istri yang bekerja ternyata berpengaruh terhadap semakin negatifnya sikap keluarga contoh terhadap program $(p=0,020)$. Hal ini dapat terjadi dikarenakan istri yang bekerja memiliki peluang yang lebih besar untuk berkomunikasi dengan orang lain dan terpapar informasi negatif tentang program. $\mathrm{Di}$ sisi lain, istrilah yang sehari-harinya berinteraksi dengan penggunaan gas sebagai produk dari program konversi.

\section{Perilaku Penggunaan}

Penelitian ini mengoperasionalkan perilaku penggunaan LPG menjadi dua yaitu menggunakan LPG dan tidak menggunakan LPG. Data menunjukkan bahwa dua pertiga keluarga contoh $(76,67 \%)$ menggunakan LPG sejak diberikan oleh aparat pemerintah terkait dan digunakan sampai penelitian dilakukan. Alasan utama $(89,13 \%)$ perilaku ini dilakukan oleh keluarga contoh adalah harga minyak tanah yang melambung tinggi dan langkanya minyak tanah di pasaran dan hanya $10,87 \%$ keluarga contoh yang beralih ke penggunaan LPG karena mereka mengetahui manfaat LPG dibandingkan minyak tanah.

Sebesar $23,33 \%$ keluarga contoh tidak menggunakan LPG saat penelitian dilakukan. Keluarga contoh yang tidak menggunakan LPG memiliki dua kecenderungan, yaitu tidak menggunakan LPG sejak produk program tersebut diberikan di awal program dan tidak menggunakan setelah pernah mencoba menggunakan untuk beberapa kali, namun sudah tidak digunakan saat penelitian dilakukan. Alasan utama yang menjadi pendorong keluarga contoh tidak menggunakan LPG sejak diberikan adalah karena takut menggunakan LPG (80\%) dan tidak diperbolehkan oleh pemilik kontrakan yang ditempati contoh (20\%). Pada kondisi ini, produk program yang tidak digunakan sebesar $80 \%$ diberikan ke keluarga lain dan $20 \%$ lainnya dijual.

Alasan keluarga contoh tidak lagi menggunakan LPG setelah beberapa kali menggunakan produk program tersebut dikarenakan sebanyak $80 \%$ memiliki rasa takut yang tinggi. Sebesar $20 \%$ keluarga contoh tidak lagi menggunakan LPG dikarenakan produk sudah rusak parah dan tidak memiliki uang untuk menggantinya. Pada kondisi ini, produk program yang sudah lagi tidak digunakan sebesar $40 \%$ diberikan kepada keluarga lain, 40\% disimpan, dan $20 \%$ dijual.

Untuk atribut tempat pembelian, separuh contoh membeli LPG isi ulang di warung. Sementara itu, untuk atribut cara pembelian, lebih dari dua pertiga keluarga contoh $(88 \%)$ melakukan pembelian secara langsung yaitu langsung mendatangi warung atau agen. Seluruh keluarga contoh melakukan transaksi pembelian secara tunai.

Berdasarkan hasil analisis, faktor yang paling berpengaruh terhadap perilaku penggunaan LPG oleh keluarga contoh adalah sikap terhadap program $(p<0,05)$.

\section{Tingkat Kepuasan}

Hasil analisis kepuasan menggunakan Costumer Satisfaction Index (CSI) menunjukkan bahwa kepuasan contoh terhadap pelaksanaan program dapat dikelompokkan kategori puas. Hal ini ditunjukkan dari nilai CSI secara keseluruhan terhadap seluruh dimensi program konversi adalah 0,74 
(rentang puas adalah bila CSI 0,66-0,80). Sementara itu, atribut terkait kualitas produk yang masih memiliki tingkat kepuasan terendah adalah kualitas selang dan regulator. Begitu pula dengan atribut sosialisasi dari pemerintah tentang penggunaan LPG dan pengawasan rutin dari petugas juga masih menunjukkan kepuasan yang rendah. Posisi CSI yang berada di rentang puas menunjukkan bahwa keseluruhan contoh sudah merasa puas dengan pelaksanaan program yang diselenggarakan oleh pemerintah. Untuk atribut terkait kualitas produk program, tingkat kepuasan terendah berada pada kualitas selang dan regulator. Contoh kerap mengambil kredit selang dan regulator untuk mengganti selang dan regulator yang diberikan oleh pemerintah yang sudah rusak. Contoh merasa sosialisasi dari pemerintah tentang penggunaan LPG masih sangat kurang, padahal menurut contoh sosialisasi itu sangat dibutuhkan karena banyak dari contoh yang masih belum terbiasa menggunakan LPG baik dikarenakan takut ataupun tidak tahu. Contoh juga mengemukakan pada awal program dilaksanakan, sering ada petugas yang bertugas mengecek keadaan tabung, namun akhirnya petugas tersebut menyarankan untuk mengganti selang dan regulator dengan alasan agar lebih aman. Kondisi ini membuat contoh merasa kedatangan petugas tidak terlalu banyak membantu karena hanya memiliki motif untuk menjual produk.

Analisis Importance Performance Analysis (IPA) yang dilakukan menempatkan harga gas serta ketahanan selang dan regulator menjadi prioritas penting bagi keluarga contoh namun belum optimal pelaksanaannya oleh pemerintah ataupun stakeholder terkait sehingga contoh belum puas untuk atribut tersebut. Ketidakpuasan terhadap atribut harga dikarenakan menurut contoh harga LPG saat ini masih cukup tinggi jika dibandingkan dengan penghasilan yang mereka dapatkan sehari-hari. Hal ini dikarenakan hampir seluruh contoh $(91,67 \%)$ keluarga contoh mendapatkan pendapatan harian sehingga contoh merasa sulit untuk melakukan manajemen penghasilan untuk membeli LPG ketika LPG habis. Ketidakpuasan atribut ketahanan selang dan regulator juga ditemui dari hasil penelitian. Hal ini bisa terjadi dikarenakan kualitas ketahanan selang dan regulator tidak memuaskan. Banyak dari contoh harus mengambil kredit untuk mengganti selang dan regulator yang sudah rusak walaupun masa pakai dari produk program tersebut belum lama.

\section{Strategi Perbaikan Program}

Strategi perbaikan program dapat dilakukan dengan cara memperbaiki mekanisme harga dan kualitas selang serta regulator. Hasil penelitian menunjukkan bahwa dua atribut tersebut pada pelaksanaannya masih jauh dari harapan contoh. Terutama pada atribut kualitas selang dan regulator, contoh menilai kualitas ketahanan selang dan regulator tidak memuaskan. Dengan memperbaiki kedua atribut tersebut secara tidak langsung pemerintah juga meningkatkan kepuasan masyarakat terhadap program ini.

Pemerintah juga perlu melakukan upaya sosialisasi untuk mengurangi sikap negatif sasaran program. Upaya ini perlu dilakukan untuk mengurangi sikap negatif sasaran program. Sosialisasi program dapat dilakukan melalui media massa ataupun langsung menyentuh masyarakat dengan mengetahui terlebih dahulu sistem keorganisasisan masyarakat sehingga informasi dapat efektif menyentuh masyarakat.

\section{KESIMPULAN DAN SARAN}

\section{Kesimpulan}

Keluarga contoh dalam penelitian ini didominasi oleh keluarga dengan kemampuan ekonomi rendah dan masuk kategori miskin. Penurunan pengeluaran bahan bakar, status pekerjaan istri, tingkat pendidikan istri, dan sikap terhadap program berpengaruh signifikan terhadap tingkat kesejahteraan keluarga sasaran. Lebih dari separuh keluarga contoh memiliki sikap negatif terhadap program. Tingkat pendidikan dan pekerjaan istri berpengaruh signifikan terhadap pembentukan sikap ini. Lebih dari dua pertiga keluarga contoh menggunakan LPG sejak diberikan dan sampai penelitian dilakukan. Sikap terhadap program berpengaruh nyata terhadap pembentukan perilaku penggunaan LPG. Secara keseluruhan, perilaku pembelian LPG dari sebagian besar contoh dilakukan secara langsung yaitu langsung mendatangi warung dan melakukan transaksi pembelian secara tunai.

Kepuasan terhadap program konversi minyak tanah ke LPG masuk kategori puas. Harga gas, kualitas selang dan regulator, dan ketersediaan agen merupakan atribut yang perlu diperbaiki oleh pemerintah. 
Melihat data yang ada, maka strategi perbaikan program dapat dilakukan dengan memperbaiki mekanisme harga serta kualitas selang dan regulator. Selain itu, upaya sosialisasi untuk mengurangi sikap negatif sasaran program menjadi salah satu alternatif strategi perbaikan program.

\section{Saran}

Berdasarkan kesimpulan yang diambil dalam penelitian ini, maka beberapa saran yang bisa direkomendasikan adalah :

1. Pemerintah perlu mengurangi sikap negatif yang dirasakan oleh keluarga contoh dengan melakukan pemasaran sosial terpadu Program Konversi Minyak Tanah ke LPG.

2. Pemerintah perlu menggalakkan program keluarga berencana kembali dan dikelola lebih baik lagi di tingkat daerah.

3. Pemerintah dapat memperbaiki kinerjanya dengan menstabilkan harga LPG di tingkat masyarakat dan menahan untuk menaikkan harga LPG untuk beberapa waktu kedepan serta meningkatkan

\footnotetext{
* Korespondensi :

Telp : +62-2518628303

Email : istiqlaliyah@yahoo.com
}

kualitas produk program seperti selang dan regulator.

\section{DAFTAR PUSTAKA}

Ahmadi A. 1999. Psikologi Sosial. Jakarta: PT Rineka Cipta.

Anonim. 2007. Blueprint Program Pengalihan Minyak Tanah ke LPG 2007-2012. www.migasesdm.go.id [02 Februari 2009].

Buttle F. 2007. Costumer Relationship Management. Jakarta: Bayumedia Publishing dengan persetujun ELSEVIER LTD, The Boulevard, Langord Lane, Kisslington, Oxford

Rambe A. 2004. Alokasi Pengeluaran Rumah Tangga dan Tingkat Kesejahteraan (Kasus di Kecamatan Medan Kota, Sumatera Utara) [tesis]. Bogor: Sekolah Pascasarjana, Institut Pertanian Bogor.

Sumarwan U. 2002. Perilaku Konsumen: Teori dan Penerapannya dalam Pemasaran. Bogor: PT Ghalia Indonesia. 